\title{
THE TERATOGENIC EFFECTS OF ETHANOLIC EXTRACT OF BINTANGUR LEAVES (CALOPHYLLUM SOULATTRI BURM. F) ON FEMALE WHITE RATS
}

\author{
INARAH FAJRIATY*, HAFRIZAL RIZA, FAJAR NUGRAHA, FRENGKI FRIANTO
}

Department of Pharmacy, Faculty of Medicine, Tanjungpura University, Pontianak, Indonesia. Email: inarah.fajriaty@yahoo.com

Received: 14 March 2019, Revised and Accepted: 24 June 2019

ABSTRACT

Objectives: Drugs can cause undesired effects on the fetus during pregnancy, especially embryonic/organogenesis which could lead to defects in the fetus because some types of drugs can penetrate the placenta and will undergo biotransformation into a highly reactive compound that has the potential to become a teratogenic compound. The aim of this research was to examine the teratogenic effect of bintangur leaves (Calophyllum soulattri Burm. F) ethanol extract to Sprague Dawley strain white rats.

Methods: The white rats are divided into four treatment groups: Control group was given carboxymethyl cellulose Na 1\%, comparison group was given trimethoprim $360 \mathrm{mg} / \mathrm{kg} \mathrm{BW}$, C. soulattri leaves ethanol extract (CLE) $100 \mathrm{mg} / \mathrm{kg} \mathrm{BW,} \mathrm{and} \mathrm{CLE} 500 \mathrm{mg} / \mathrm{kg}$ BW. The treatment was administrated since organogenesis period. Cesarian section was performed to pregnant rat at the $20^{\text {th }}$ day to separate the fetuses. Observation covered body weight of pregnant rats, fetal biometric, morphological malformation, and skeletal formation.

Results: CLE $100 \mathrm{mg} / \mathrm{kg} \mathrm{BW}$ and $500 \mathrm{mg} / \mathrm{kg}$ BW did not cause any change in the number of a living fetus, body weight, and length of fetuses like the comparison group. Both doses of CLE shown have a normal skeletal formation. Resorption was found in the comparison group and CLE 100 mg/kg BW with the percentage was $65.21 \%$ and $6.67 \%$. It was found that there is no significant difference (p<0.05) between both doses of CLE compared to control group.

Conclusion: From the results, it is concluded that CLE did not have the teratogenic effect.

Keywords: C. soulattri leaves ethanol extract, Rat, Fetus, Estrus, Teratogenic, Gestation.

(C) 2019 The Authors. Published by Innovare Academic Sciences Pvt Ltd. This is an open access article under the CC BY license (http://creativecommons. org/licenses/by/4. 0/) DOI: http://dx.doi.org/10.22159/ajpcr.2019.v12i8.33086

\section{INTRODUCTION}

Drugs can cause undesired effects on the fetus during pregnancy, especially embryonic/organogenesis which could lead to defects in the fetus [1]. Infant's disability at birth is about $2-5 \%$ [2]. About $2-3 \%$ of them allegedly caused by taking the drug because some types of drugs consumed by pregnant women can penetrate the placenta and will undergo biotransformation into a highly reactive compound so that its use needs to be careful [3].

At present, modern medicines endure our routine life. However, lately, this treatment returns to medicinal plants traditionally [4]. Natural products serve as the lead compounds for the development of new medicine and drug discovery [5]. Calophyllum is widely used in traditional Chinese medicine to treat inflammation and rheumatism [6]. Calophyllum soulattri leaves in Indonesia are also used to rinse inflamed eyes [7]. The soulatron A compound of triterpenoid derivatives that are isolated from C. soulattri leaves is used as anti-inflammatory [8]. Xanton, coumarin, chromanone, acylphloroglucinol, terpenoids, and steroids are secondary metabolite compounds that were isolated from the genus Calophyllum [6]. Last studies have suggested that oral administration of $C$. soulattri leaves ethanol extract (CLE) repeatedly for 28 days did not cause an alteration in histological of the spleen [9]. Compounds that have been isolated from C. soulattri are soulattrin (xanton derivate) which has cytotoxic activity with $\mathrm{IC}_{50}$ value of $2.77 \pm 0.59$ to HeLa cell [10]. The natural product which is used as medicines should in compliance with the guidelines that the drug does not cause acute or chronic toxicity and proves efficacious as a medicinal [11]. Therefore, testing of the teratogenic effects of $C$. soulattri leaves needs to be done because basically, plants that have cytotoxic activity have the potential to kill cells and potentially as teratogens that can cause abnormalities or defects in the embryo [12].

\section{MATERIALS AND METHODS}

\section{Materials}

C. soulattri were selected for this study and were from West Borneo, Indonesia. The other materials are aquades, Bouin solution, buffer formaldehyde, carboxymethyl cellulose $\mathrm{Na}$, ethanol $90 \%, \mathrm{NaCl} 0.9 \%$, and trimethoprim.

\section{Experimental animal preparation}

Estrous cycle was determined by vaginal smears on a microscope observation. Three female rats that were in proestrus to estrus cycle were mated with one male rat and kept overnight in a cage. If sperm was detected in the vaginal smears the next morning, it was expressed as the $0^{\text {th }}$ gestation day. The body weight of pregnant rats was recorded until the $20^{\text {th }}$ gestation day [13].

\section{Teratogenic effects test}

The treatment was given during the organogenesis period $\left(6^{\text {th }}\right.$ $17^{\text {th }}$ gestation day). Cesarian section was performed to pregnant rat at the $20^{\text {th }}$ day to separate the fetuses. The number of live fetuses, resorption, and morphological abnormalities was recorded [14].

\section{Skeletal preparation}

The fetus was fixed by ethanol for 1 week. The fetus was skinned and the internal organs were removed. Fetuses were fixed by potassium hydroxide $0.5 \%$ solution for not $<24 \mathrm{~h}$ and then by hydrogen peroxide $1 \%$ for $2-3 \mathrm{~h}$. The fetus was soaked by aquades for $10 \mathrm{~min}$ and then immersed in alizarin solution for not $<24 \mathrm{~h}$. The fetus is gradually soaked in a solution of $5,20,40$, and $80 \%$ glycerol for each week [13]. 
Data analysis

Statistical analysis was performed by the SPSS version 22.0 program with one-way analysis of variance test. All the data were evaluated with a $95 \%$ confidence level $(\mathrm{p}<0.05)$.

\section{RESULTS AND DISCUSSION}

\section{Estrous cycle}

Estrous cycle was observed using a $\times 40$ magnification microscope. The result showed that the rats estrous cycle was normal at 5 days (Fig. 1) [15]. Estrous cycle is a reproductive phase in non-primate female animals that occur repeatedly, marked by changes in physiology and behavior. The estrous cycle in rodents lasts $4-5$ days, consisting of four phases, namely, proestrus, estrus, metestrus, and diestrus [16]. Three female rats that were in proestrus to estrus cycle were mated with one male rat because only the female mice in the estrus phase are willing to mate [17]. The treatment was given during the organogenesis period on the $6^{\text {th }}$ until the $17^{\text {th }}$ gestation day.

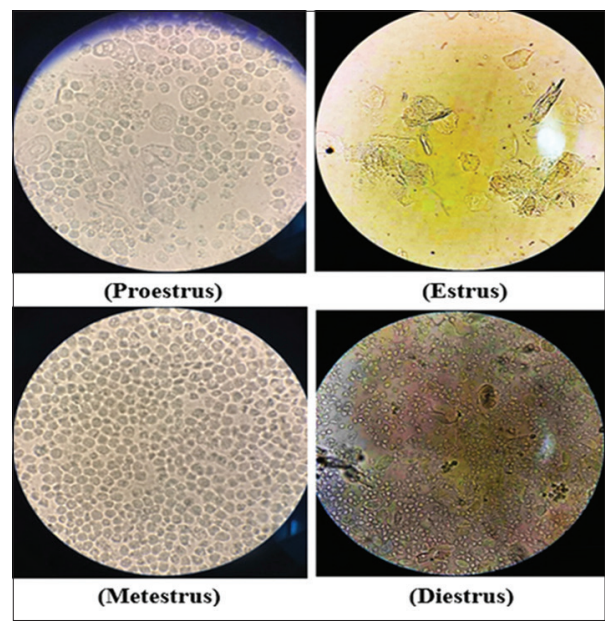

Fig. 1: Estrous cycle
Body weight of pregnant rats

The result showed that the comparison weight of the pregnant rats' group on the $20^{\text {th }}$ day differs considerably by the pregnant body weight with the other group (Fig. 2) on day 20. This can occur because on the past 3 days of pregnancy, the resorption rate increases and causes fetal weight to decrease so that it can also cause a decrease in the pregnant rats' weight. The weight of the parent can also be a description of the quantity or weight of the fetus produced so that in the comparison group, the fetus produced is smaller or less than the other groups. Weight loss is the mildest form of teratogenic compounds effect [18].

\section{The extract effect on the weight of uterus}

Examination of uterine weight was done after it was separated. Control group, CLE $100 \mathrm{mg} / \mathrm{kg} \mathrm{BW}$, and CLE $500 \mathrm{mg} / \mathrm{kg}$ BW showed a significant difference to comparison group in uterine weight parameter $(p<0.05)$. The result showed that the uterine weight of the comparison group was the smallest among other groups (Fig. 3). This is related to the number of fetuses produced. The more fetuses that are produced, the uterus will be longer and heavier during pregnancy [18]. A substance that can affect the uterus may also affect the growth of the fetus so that are produced, the uterus in the parent will be longer so that the uterus will also be more difficult to adjust the number that a decrease in uterine weight may also affect fetal weights [19].

\section{Fetus biometric}

The cesarean section was performed at the $20^{\text {th }}$ gestation day. This prevents the occurrence of cannibalism because the rat that gives birth normally will tend to eat their defective heredity so it can interfere with the observation of fetal abnormalities. Table 1 shows that the control group did not show any mortality or resorption. The comparison group had $65.21 \%$ of resorption fetus. CLE $100 \mathrm{mg} / \mathrm{kg}$ BW shows that the percentage of the live fetus was $93.33 \%$ and resorption was $6.67 \%$. The percentage of the live fetus in CLE $500 \mathrm{mg} / \mathrm{kg}$ BW groups was $100 \%$. Resorption is a condition in which the fetus cannot develop into a normal fetus at the site of implantation. Resorption can be caused by morphological abnormalities with various body defects that end in death [20]. The resorption of the fetus is one indication of a teratogenic effect [21]. Trimethoprim was used as a comparison group because

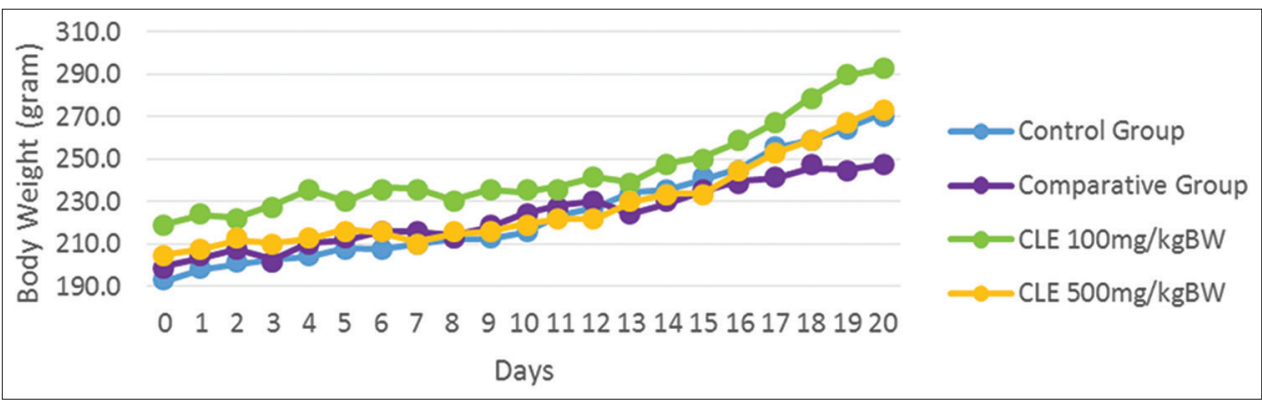

Fig. 2: Body weight of pregnant rats

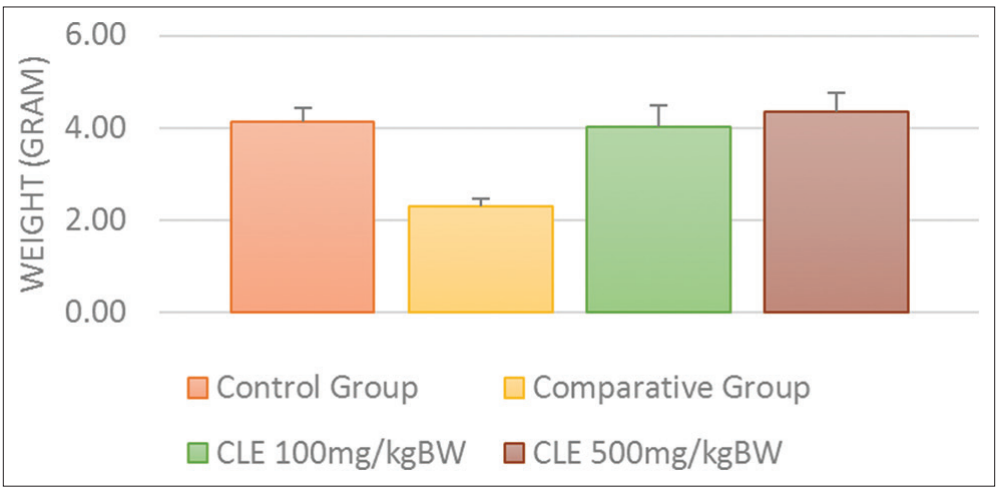

Fig. 3: Uterine weight 

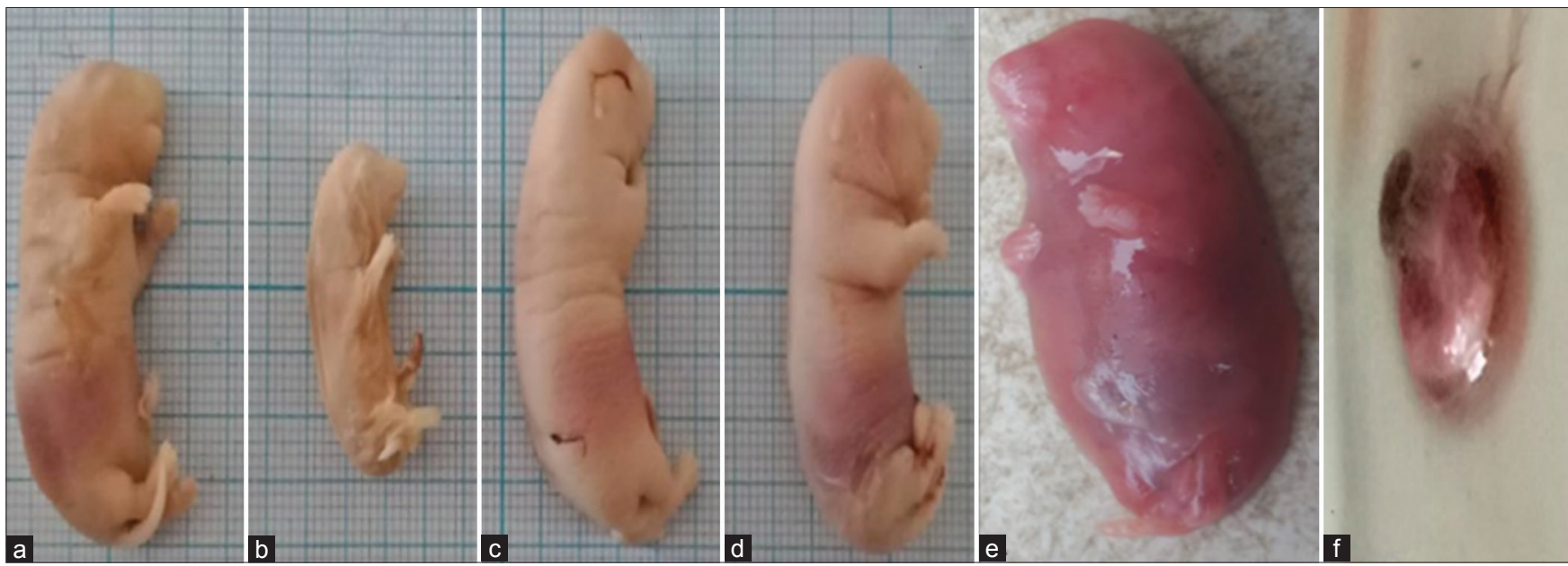

Fig. 4: Fetus each group. (a) Control group, (b) Comparative group, (c) Calophyllum soulattri leaves ethanol extract (CLE) $100 \mathrm{mg} / \mathrm{kg}$ BW, (d) CLE $500 \mathrm{mg} / \mathrm{kg} \mathrm{BW}$, (e) Hemorrhage in comparative group, (f) Resorption in comparative group

Table 1: Fetus percentage

\begin{tabular}{lllll}
\hline \multirow{2}{*}{ No. } & Group & \multicolumn{3}{c}{ Fetus percentage (\%) } \\
\cline { 3 - 5 } & & Live & Dead & Resorption \\
\hline 1 & Control group & 100 & 0 & 0 \\
2 & Comparison group & 34.78 & 0 & 65.21 \\
3 & CLE 100 mg/kg BW & 93.33 & 0 & 6.67 \\
4 & CLE 500 mg/kg BW & 100 & 0 & 0 \\
\hline
\end{tabular}

trimethoprim is one of the teratogenic drugs by inhibiting folic acid synthesis [22]. Trimethoprim inhibits dihydrofolate reductase which reduces dihydrofolic acid to tetrahydrofolic acid which results in the cessation of folic acid synthesis [23]. Folic acid is a very important compound during the time of organogenesis, especially in the nervous system [22]. If there is no folat acid, it can interfere with fetal development [12].

\section{The extract effect on the weight of fetus}

Based on Fig. 4, the fetus of CLE $100 \mathrm{mg} / \mathrm{kg} \mathrm{BW}$ has the largest size among the other groups. The fetus of control group has the same size with CLE $500 \mathrm{mg} / \mathrm{kg}$ BW. The fetus of the comparison group has the smallest size due to the fetus becomes dwarfed. The fetus of the comparison group also showed a hemorrhage. Hemorrhage in the comparison group occurs due to the teratogenic effects caused by trimethoprim, which are defects in the cardiovascular system. Observations were also performed on the fetal body weight of each group which is a fairly sensitive parameter. The result showed that CLE did not affect the weight of the fetus. Based on Fig. 5, it can be seen that there is no significant difference between the control group, CLE $100 \mathrm{mg} / \mathrm{kg} \mathrm{BW}$, and CLE $500 \mathrm{mg} / \mathrm{kg}$ BW. Significant differences occurred in the control group, CLE $100 \mathrm{mg} / \mathrm{kg} \mathrm{BW}$, and CLE $500 \mathrm{mg} / \mathrm{kg}$ BW with comparison group $(\mathrm{p}<0.05)$. Decreased fetal weight is the lightest effect of the effects of teratogenous compounds so that it can be used as a parameter for fetal growth inhibition due to disruption of growthbased processes such as cell division, cell interactions, metabolism, and biosynthetic reduction in cells such as nucleic acid synthesis, protein, and mucopolysaccharides [24].

\section{Morphological observation}

Fetuses in all of the treatment groups look normal with no defects outside the body. The morphological observation was performed to see the physical disability of the fetus including the completeness of hands, feet, ears, eyes, nose, lips tail, and congestion. Physical defects were not found in all groups.

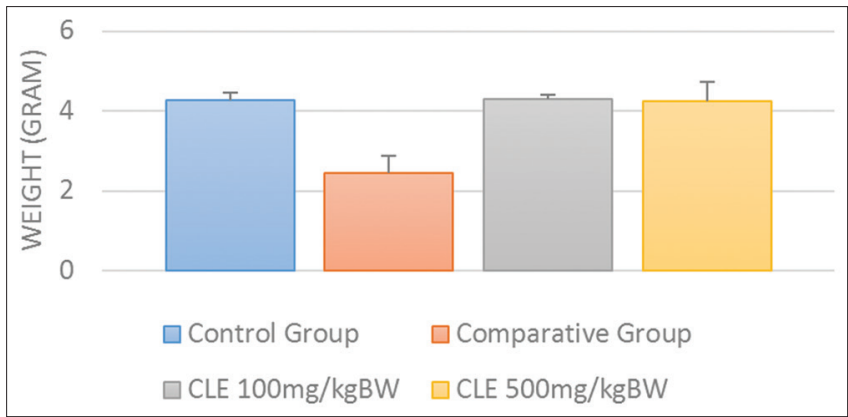

Fig. 5: Fetus weight
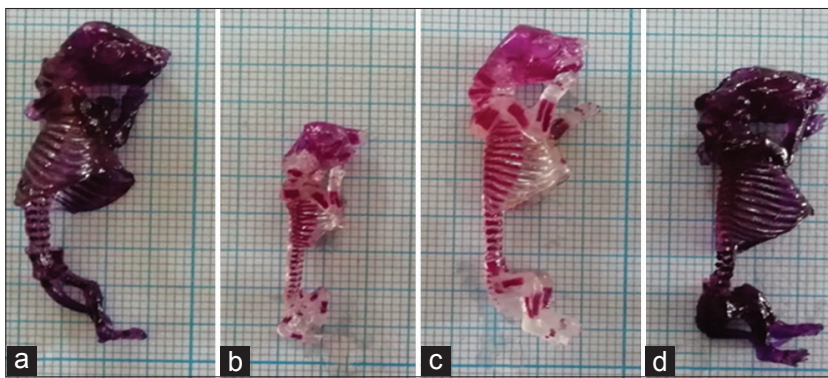

Fig. 6: Skeletal system of the Fetus with Alizarin Red staining [Documentation]. (a) Control group, (b) Comparison group, (c) Calophyllum soulattri leaves ethanol extract (CLE) $100 \mathrm{mg} / \mathrm{kg} \mathrm{BW}$, (d) CLE $500 \mathrm{mg} / \mathrm{kg} \mathrm{BW}$

\section{The extract effect on skeletal formation}

Observations on the growth of skeleton fetus Sprague Dawley rat strains were performed using Alizarin Red [13]. Staining with Alizarin Red or sodium alizarinsulfonate was used to detect bone classification in the fetus. Alizarin will bind calcium to the bone matrix so that the bone in the fetus will be dark purple [25]. The normal fetus should have 7 cervical bones, 13 thoracic bones, 6 lumbar bones, and 4 sacral bones [26]. Based on skeletal observation (Fig. 6), there was no spinal disability which was found in all groups.

Observation were also performed with a microscope at $40 \times$ magnificationand there were defect in the fetal ribs of the comparison group (Fig. 7). The form of disability that occurred was the presence of a fused rib. The fused ribs indicate that the ossification process was not perfect. This is due to the mechanism of trimethoprim in inhibiting folic acid synthesis so that the ossification process is disrupted. The 


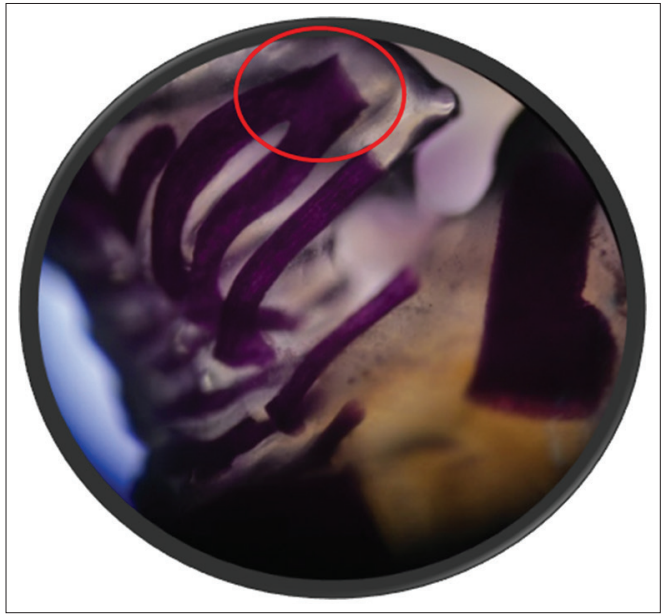

Fig. 7: Defects in fetus ribs

disbalance between the bone-building activities of osteoclasts causes osteoporosis, resulting in increased bone loss and decreased bone replacement [27].

\section{CONCLUSION}

Ethanolic extract of C. soulattri leaf at doses of $100 \mathrm{mg} / \mathrm{kg} \mathrm{BW}$ and $500 \mathrm{mg} / \mathrm{kg}$ BW did not give teratogenic effect on Sprague Dawley white rats seen from fetal biometric parameters, gross morphology, and skeletal system. The dose of the ethanolic extract of $C$. soulattri leaf that causes the teratogenic effect is thought to be above $500 \mathrm{mg} / \mathrm{kg} \mathrm{BW}$.

\section{AUTHORS' CONTRIBUTIONS}

All authors had equally contributed to the work.

\section{CONFLICTS OF INTEREST}

Authors declare no conflicts of interest.

\section{REFERENCES}

1. Departemen Kesehatan Republik Indonesia. Pedoman Pelayanan Farmasi untuk Ibu Hamil dan menyusui. Jakarta: Departemen Kesehatan Republik Indonesia; 2005.

2. Haroun H. Teratogenicity and teratogenic factors. Med Crave 2017;3 Suppl 1:82

3. World Health Organization. WHO Drug Information. Vol. 1. Geneva: World Health Organization; 1987.

4. Fajriaty I, Hariyanto IH, Youngky H. Anti-fertility effect of ethanol extract of lerak (Sapindus rarak DC) fruits in female sprague dawley rats. Nusantara BioSci 2017;9 Suppl 1:102-6.

5. Riza H, Fahrurroji A, Wicaksono A, Nugroho A, Martono S. Docking study of methyl hesperidin as nucleoside reverse transcriptase inhibitor.
Int J Pharm Pharm Sci 2018;10 Suppl 3:85-9.

6. Ee GC, Mah SH, Teh SS, Rahmani M, Go R, Taufiq-Yap YH, et al. Soulamarin, a new coumarin from stem bark of calophyllum soulattri. Molecules 2011;16:9721-7.

7. Heyne K. Tumbuhan Berguna Indonesia III. Jakarta: Badan Litbang Kehutanan; 1987.

8. Nigam SK, Banerji P, Rebuffat S, Caesario M. Pawards M, Bernard B. Soulatrone a. $\mathrm{A} \mathrm{C}_{24}$ terpenoid from Calophyllum soulattri. Phytochemistry 1998;27 Suppl 2:527-30.

9. Fajriaty I, Apridamayanti P, Rahmawani S, Abdurrachman A. Transaminase enzymes and lipid profiles and histological changes in Wistar rats after administration of bintangur (Calophyllum soulattri) leaves ethanolic extract. Nusantara BioSci 2018;10 Suppl 1:27-35.

10. Mah SH, Ee GC, Teh SS, Rahmani M, Lim YM, Go R, et al. Phylattrin, a new cytotoxic xanthone from calophyllum soulattri. Molecules 2012;17:8303-11.

11. Fajriaty I, Adnyana I, Fidrianny I. Acute and sub-chronic (28 days) repeated oral toxicity test of ethanol extract of lerak (Sapindus rarak. DC) fruits in wistar rats. Int J Pharm Pharm Sci 2014;6 Suppl 11:487-92.

12. Widyastuti N, Widiyani T, Listyawati S. Teratogenic effect of Phaleria macrocarpa (Scheff.) Boerl. Fruit extract on rat (Rattus norvegicus L.) winstar strain. Bioteknologi 2006;3 Suppl 2:56-62.

13. Badan Pengawas Obat dan Makanan Republik Indonesia. Prosedur Operasional Baku Uji Toksisitas Praklinik. Jakarta: Pusat Riset Obat dan Makanan Badan Pengawas Obat dan Makanan Republik Indonesia;2009.

14. OECD (Organization for Economic Cooperation and Development). Guidelines for Testing Chemicals. Washington, D.C: OECD Publication and Information Center; 1987.

15. Rafferty K. Method in Experimental Embryology of The Mouse. London: The John Hopkins Press; 1970.

16. Bertolin K, Murphy B. Reproductive Tract Changes During the Mouse Estrous Cycle. London: Academic Press; 2014

17. Nalbandov A. Fisiologi Reproduksi Pada Mamalia Dan Unggas. Jakarta: Universitas Indonesia Press; 1990.

18. Guyton A. Textbook of Medical Physiology. $5^{\text {th }}$ ed. Jakarta: EGC; 1983.

19. Pudjiastuti, Sa'roni S, Widowati L. Pengaruh Kaempferia galanga L. (Kencur) terhadap perkembangan janin tikus putih. Warta Tanaman Obat Indonesia 1996;3 Suppl 2:31.

20. Peter P, Beerkvens J. General Reproduction Toxicology. New York: CRC Press; 1996.

21. Santoso $H$. The effect of caffeine on reproductive appearance and growth of mouse mice skeleton (Mus musculus L.). J Biol 2006;1:39-48.

22. Hansen C, Andrade SE, Freiman H, Dublin S, Haffenreffer K, Cooper WO, et al. Trimethoprim-sulfonamide use during the first trimester of pregnancy and the risk of congenital anomalies. Pharmacoepidemiol Drug Saf 2016;25:170-8.

23. Tjay T, Rahardja K. Obat-obat Penting Khasiat, Penggunaan Dan Efek-efek Sampingnya Edisi Keenam. Jakarta: PT. Elex Media Komputindo; 2007.

24. Wilson J, Fraser F. Handbook of Teratology: General Principles and Etiology. Vol. 1. New York: Plenum Press; 1977.

25. Jasin M. Sistematika Hewan (Invertebrata Dan Vertebrata). Surabaya: Sinar Wijaya; 1989.

26. Taylor P. Practical Teratology. London: Academic Press; 1986

27. Pankova S, Tsvetkova D. Role of phytoestrogens in prevention of osteoporosis. Int J Curr Pharm Res 2015;7 Suppl 2:1-6. 